\title{
Arquitetura em Vídeo e foto: INTERMEIOS NA FAUUSP
}

\author{
Sheila Walbe Ornstein
}

A Faculdade de Arquitetura e Urbanismo da Universidade de São Paulo (FAUUSP) lança o site www.fau.usp.br/intermeios, agregando a sua longa experiência no trato de vídeos e de fotos em Arquitetura e Urbanismo. Com mais de vinte anos de produção de documentários de curta duração e fotos que traduzem de forma didática as mais diversas facetas da prática profissional do arquiteto, urbanista e paisagista, Intermeios procura contar o percurso desta produção imagética de qualidade que se confunde com a própria história da FAUUSP na sua trajetória plural e interdisciplinar com mais de sessenta anos.

Desde a origem do então Laboratório Fotográfico da FAUUSP no qual, docentes, técnicos especializados e estudantes aprendiam a incorporar o esplendor e a força das imagens estáticas em branco e preto na demonstração da concepção arquitetônica até a inserção das imagens digitais coloridas e aquelas em movimento - os vídeos - uma extensa geração de profissionais puderam se aperfeiçoar no uso de técnicas e equipamentos, atualmente de alta tecnologia, para não só demonstrar as suas ideias sobre Urbanismo, Paisagismo, Arquitetura, detalhes construtivos, mas também para fazerem destas imagens, a profissão em si que escolheram abraçar.

Intermeios, o site, revela o apuro com as imagens conforme descrito acima. A navegação neste site mostra, por exemplo, a série de documentários sobre o projeto e a construção do Museu Brasileiro da Escultura, do arquiteto Paulo Mendes A. da Rocha, o uso da taipa, em todas as suas peculiaridades pelas populações rurais, a produção histórica do ladrilho hidráulico, o sítio arqueológico dos Erasmos, a produção industrial de Michel Arnoult, o projeto, a construção e o cotidiano da vida no edifício Copan e outros temas tão tocantes para a cidade contemporânea como o desenho universal. Na linguagem destes vídeos, destacase a preocupação com o didatismo, o convite para estudantes e profissionais a produções cuidadosas quanto ao roteiro, à captação de imagens, o uso de animações e de entrevistas, suficientes para um breve aprendizado, uma introdução a uma aula, sempre mantendo o equilíbrio entre o contexto acadêmico e, portanto com informações corretas oriundas de pesquisas docentes e discentes e o "quero mais". Não é à toa que vários destes documentários foram premiados nacional e internacionalmente.

Intermeios abre, enfim, a possibilidade de reunião desta produção conjunta vídeo e foto - e a disponibiliza aos interessados. É de fato um convite a uma leitura arquitetônica, afiada enquanto informação, mas sem perder a sutileza da poesia que comove a todos.

\section{Sheila Walbe Ornstein}

Professora titular FAUUSP, pesquisadora do CNPq, ex-coordenadora do VideoFAU. Atualmente, diretora do Museu Paulista.

sheilawo@usp.br 